
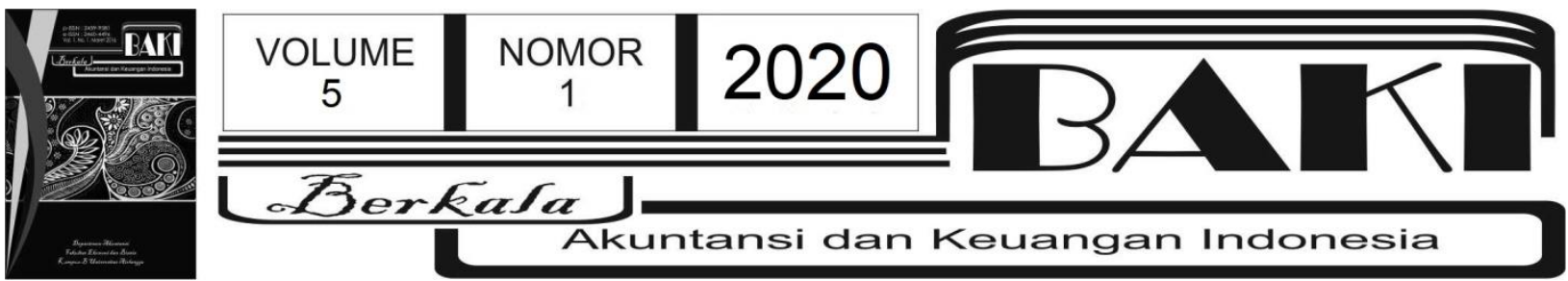

\title{
Evaluasi Pendapatan Asli Daerah (PAD) Kabupaten/Kota di Provinsi Sulawesi Tengah Tahun 2014-2018
}

\author{
Syamsul $^{1 \mathrm{a}}$
}

1STIE Panca Bhakti Palu

${ }^{a}$ correspondingauthor: syamsulsyahrir@gmail.com

\begin{tabular}{|c|c|}
\hline INFO ARTI & \\
\hline $\begin{array}{l}\text { Histori Artikel: } \\
\text { Tanggal Masuk } 17 \text { Februari } \\
2020 \\
\text { Tanggal Diterima } 30 \text { Maret } \\
2020 \\
\text { Tersedia Online } 15 \text { Mei } 2020\end{array}$ & $\begin{array}{l}\text { This study aims to evaluate the own source revenue (PAD) at district } \\
\text { level in Central Sulawesi Province in 2014-2018. Based on } \\
\text { descriptive analysis, the results found that among four sources of } \\
\text { PAD, only other legitimate revenue that have an average growth rate } \\
\text { over } 50 \text { percent and the degree of contribution is more than } 50 \\
\text { percent. Accordingly, the overall growth rate of PAD is very low (less }\end{array}$ \\
\hline & $\begin{array}{l}\text { level of PAD contribution to regional income is still very low (less than } \\
10 \text { percent) and classified as very poor. }\end{array}$ \\
\hline
\end{tabular}

Kata Kunci:

Pendapatan Asli Daerah

(PAD),

Pertumbuhan,

Kontribusi

\begin{abstract}
A B S TR A K
Penelitian ini bertujuan untuk mengevaluasi pendapatan asli daerah (PAD) kabupaten/kota di Provinsi Sulawesi Tengah tahun 2014-2018. Berdasarkan analisis deskriptif ditemukan bahwa dari empat sumber (komponen) PAD yang memiliki rata-rata tingkat pertumbuhan di atas dari 50 persen dan derajat kontribusi lebih dari 50 persen, yaitu hanya lain-lain pendapatan asli daerah yang sah. Kemudian, secara keseluruhan tingkat pertumbuhan PAD masih sangat rendah (kurang dari 30 persen) dan termasuk dalam kualifikasi tidak berhasil. Sementara itu, tingkat kontribusi PAD terhadap pendapatan daerah masih sangat sedikit (kurang dari 10 persen) dan tergolong dalam kualifikasi sangat kurang baik.
\end{abstract}




\section{Pendahuluan}

Undang-Undang (UU) Nomor 32 Tahun 2004 dan UU Nomor 33 Tahun 2004 sebagai landasan utama praktik otonomi daerah dan desentralisasi fiskal di Indonesia. Tujuan utama diberlakukannya regulasi tersebut adalah untuk mewujudkan pertumbuhan ekonomi dan kesejahteraan masyarakat yang merata di seluruh lapisan masyarakat. Intinya, tujuan itu akan tercapai, apabila ditopang oleh sumber pendanaan (pendapatan daerah) yang optimal dalam membiayai program daerah (belanja daerah). Dua kelompok utama sumber pendanaan daerah, yaitu pendapatan asli daerah (PAD) berasal dari pemerintah daerah dan dana perimbangan dari pemerintah pusat. Sebagaimana juga dikemukakan oleh Craw (2010) bahwa upaya mewujudkan kesejahteraan penduduk, pemerintah daerah membutuhkan sumber dana yang diperoleh dari kapasitas fiskal dan bantuan dari pemerintah pusat.

Tabel 1.1. Realisasi Pendapatan Daerah Kabupaten/Kota Di Provinsi Sulawesi Tengah Tahun 2014-2018 (dalam ribuan rupiah)

\begin{tabular}{|c|c|c|c|c|c|c|}
\hline \multirow{2}{*}{$\begin{array}{c}\text { Nama Kabupaten/ } \\
\text { Kota }\end{array}$} & \multicolumn{5}{|c|}{ Pendapatan Daerah } & \multirow{2}{*}{ Rata-rata } \\
\hline & 2014 & 2015 & 2016 & 2017 & 2018 & \\
\hline Kab. Parigi Moutong & $973,572,706$ & $1,168,381,300$ & $1,469,285,281$ & $1,449,457,798$ & $1,447,095,259$ & $1,301,558,469$ \\
\hline Kab. Donggala & $854,226,692$ & $1,084,867,390$ & $1,266,899,313$ & $1,136,593,525$ & $1,178,494,165$ & $1,104,216,217$ \\
\hline Kab. Sigi & $761,741,007$ & $933,843,014$ & $1,212,221,064$ & $1,097,233,336$ & $1,155,027,343$ & $1,032,013,153$ \\
\hline Kab. Poso & $473,464,934$ & $835,127,978$ & $923,703,293$ & $1,287,408,975$ & $1,310,352,426$ & $966,011,521$ \\
\hline Kab. Tolitoli & $745,524,216$ & $865,458,406$ & 3,000 & $1,107,426,358$ & $1,052,419,052$ & 62,206 \\
\hline Kab. Banggai & $1,198,950,867$ & $1,381,027,258$ & $1,663,759,377$ & $1,855,045,844$ & $1,994,378,669$ & 532,403 \\
\hline Kab. Banggai Laut & $201,403,210$ & $436,519,923$ & $549,813,147$ & $619,309,794$ & $611,825,522$ & 774,319 \\
\hline Kab. Banggai Kepulauan & $486,705,749$ & $606,230,529$ & $704,938,365$ & $764,650,292$ & $813,377,233$ & $675,180,434$ \\
\hline Kab. Morowali & $894,453,131$ & $835,127,978$ & $945,930,993$ & $1,144,840,491$ & $1,598,815,372$ & $1,083,833,593$ \\
\hline Kab. Morawali Utara & $516,779,813$ & $681,053,111$ & $869,147,173$ & $889,947,144$ & $1,004,625,627$ & $792,310,574$ \\
\hline Kab. Tojo Una-Una & $761,741,007$ & $933,843,013$ & $1,212,221,064$ & $961,582,935$ & $1,006,434,114$ & $975,164,427$ \\
\hline Kab. Buol & $626,648,520$ & $834,939,992$ & $902,028,568$ & $938,746,233$ & $984,310,385$ & $857,334,740$ \\
\hline Kota Palu & $998,143,074$ & $1,171,610,175$ & $1,324,405,920$ & $1,340,647,283$ & $1,351,100,284$ & $1,237,181,347$ \\
\hline Rata-rata & $730,258,071$ & $905,233,082$ & $1,074,564,351$ & $1,122,530,001$ & $1,192,942,727$ & $1,005,105,646$ \\
\hline
\end{tabular}

Sumber: data diolah tahun, 2019

Pada tabel 1.1 di atas adalah realisasi pendapatan daerah kabupaten/kota di Provinsi Sulawesi Tengah tahun 2014-2018. Dari tabel 1 tersebut terlihat bahwa rata-rata realisasi pendapatan daerah kabupaten/kota di Provinsi Sulawesi Tengah tahun 2014-2018 adalah sebesar Rp1.005.105.646.000,00. Selama lima tahun tersebut terlihat bahwa rata-rata realisasi pendapatan daerah mengalami peningkatan setiap tahunnya yaitu pada tahun 2017 sebesar Rp730.258.071.000,00. Kemudian pada tahun 2018 naik menjadi Rp905.233.082.000,00, begitupula pada tahun 2016 dan tahun 2017, juga mengalami kenaikan berturut-turut sebesar Rp1.074.564.351.000,00, dan Rp1.122.530.001.000,00. Sementara itu, pada tahun 2018 mengalami penurunan meskipun tidak terlalu signifikan menjadi Rp1.192.942.727.000,00. Selain itu, realisasi pendatapan daerah antar kabupaten/kota di Provinsi Sulawesi Tengah tahun 2014-2018 terlihat sangat fluktuatif yaitu antara Rp483.774.319.000,00 sampai dengan 
Rp1.618.632.403.000,00. Oleh karena itu, sangat menarik untuk ditelusuri lebih jauh terkait dengan pertumbuhan dan kontribusi dari setiap jenis (sumber) pendapatan daerah tersebut, khususnya dari sumber pendapatan asli daerah (PAD).

Menurut Lindaman et al. (2016) daerah dengan pendapatan yang berasal dari sumber daerah yang tinggi memiliki kecenderungan dapat memenuhi kebutuhan masyarakatnya dan lebih mampu membiayai program yang lebih banyak. Senada dengan itu, Lobao, Jeanty, Partridge, \& Kraybill, (2012) juga mengemukakan bahwa pemerintah daerah memiliki peran besar dalam pertumbuhan ekonomi dan pengurangan kemiskinan melalui kapasitas yang mereka miliki salah satunya adalah PAD. PAD adalah penerimaan daerah yang diperoleh dari kekayaan milik daerah sendiri yang dikelola berdasarkan peraturan daerah dan peraturan perundang-undangan yang berlaku. Empat sumber PAD yaitu pajak daerah, retribusi daerah, pengelolaan kekakayaan daerah yang dipisahkan, dan lain-lain pendapatan asli daerah yang sah.

Selain itu, PAD adalah wujud nyata dari derajat desentralisasi fiskal suatu daerah. Artinya semakin tinggi PAD, maka semakin tinggi pula derajat desentralisasi fiskal daerah tersebut. Begitupula, semakin kecil PAD suatu daerah, maka semakin rendah pula derajat desentralisasi daerah tersebut. Dengan kata lain, daerah dengan PAD yang rendah menunjukkan bahwa daerah tersebut masih sangat tergantung dari pemerintah pusat. Hal tersebut tentunya mengindikasikan gagalnya pemerintah daerah dalam mengoptimalkan potensi daerahnya dalam membiayai belanja daerahnya.

Penelitian ini lanjutan dari penelitian Syamsul and Fifiani (2018) yang menganalisis pertumbuhan dan kontribusi setiap komposisi dari setiap komponen PAD terhadap PAD dan dampaknya terhadap pendapatan daerah Kabupaten Parigi Moutong. Berbeda dengan lingkup penelitian sebelumnya, penelitian ini menitiberatkan pada pertumbuhan dan kontribusi dari setiap komponen PAD terhadap PAD dan pendapatan daerah kabupaten/kota di Provinsi Sulawesi Tengah. Intinya, penelitian sebelumnya hanya berfokus pada satu kabupaten saja, sementara penelitian ini menganalisis 13 kabupaten/kota di Provinsi Sulawesi Tengah. Penelitian ini penting untuk menggabarkan sejauh mana pertumbuhan dan kontribusi dari komponen PAD terhadap PAD dan pendapatan daerah di Provinsi Sulawesi Tengah.

Berdasarkan hal tersebut di atas, artikel ini hadir untuk mengevaluasi pendapatan daerah dari sumber PAD beserta komponennya. Lebih khusus penelitian ini bertujuan untuk menggambarkan tingkat pertumbuhan komponen PAD, dan tingkat kontribusi komponen PAD terhadap PAD, serta kontribusi PAD terhadap pendapatan daerah. Informasi terkait dengan hal tersebut, bermanfaat untuk dijadikan sebagai salah satu sumber rujukan bagi daerah terkait dengan pengelolaan (peningkatan) PAD dimasa mendatang, baik dari segi pertumbuhan maupun kontribusinya terhadap pendapatan daerah. 


\section{Tinjauan Pustaka}

\subsection{Pendapatan Daerah}

Pendapatan daerah adalah semua penerimaan uang melalui rekening kas umum daerah yang menambah ekuitas dana, merupakan hak daerah dalam satu tahun anggaran dan tidak perlu dibayar kembali oleh daerah. Pendapatan daerah dibagi menjadi dua kelompok yaitu pendapatan asli daerah (PAD) dan dana perimbangan.

\subsection{Pendapatan Asli Daerah (PAD)}

Pendapatan Asli Daerah (PAD) menurut Undang-Undang No.33 Tahun 2004 adalah pendapatan yang diperoleh daerah yang dipungut berdasarkan peraturan daerah sesuai dengan peraturan perundang-undangan. Kelompok PAD dibagi menurut jenis pendapatan berdasarkan Permendagri 59 Tahun 2007 tentang perubahan Permendagri 13 Tahun 2006, yaitu pajak daerah, restribusi daerah, hasil pengelolaan kekayaan milik daerah yang dipisahkan dan pendapatan asli daerah lainnya yang sah.

\subsection{Pajak Daerah}

Pajak daerah menurut Undang-Undang No. 28 Tahun 2009 tentang pajak daerah dan retribusi daerah adalah kontribusi wajib kepala daerah yang terutang oleh orang pribadi atau badan yang bersifat memaksa berdasarkan undang-undang dengan tidak mendapatkan imbalan secara langsung dan digunakan untuk keperluan daerah bagi sebesar-besarnya kemakmuran rakyat. Pajak yang dipungut oleh pemerintah provinsi dan yang dipungut oleh pemerintah daerah berbeda berdasarkan Permendagri No. 21 Tahun 2011. Pendapatan pajak untuk provinsi meliputi pajak dan bea balik nama kendaraan bermotor, pajak dan bea balik nama kendaraan di air, pajak bahan bakar kendaraan bermotor, pajak air permukaan, dan pajak rokok, sedangkan pendapatan pajak yang dipungut pemerintah daerah adalah pajak hotel, restoran, hiburan, reklame, penerangan jalan, pengambilan bahan galian golongan $\mathrm{C}$, lingkungan, mineral bukan logam dan bantuan, parkir, burung walet, bumi dan bangunan pedesaan dan perkotaan, dan BPHTB.

\subsection{Retribusi Daerah}

Retribusi menurut Undang-Undang No. 28 Tahun 2009 tentang Pajak dan Retribusi 
Daerah adalah pungutan daerah sebagai pembayaran atas jasa dan atau pemberian izin tertentu yang khusus disediakan dan/atau diberikan oleh pemerintah daerah untuk kepentingan orang pribadi atau badan. Jenis retribusi daerah yang dipungut oleh pemerintah daerah adalah retribusi yang dipungut atas jasa umum, retribusi yang dipungut atas jasa khusus, dan retribusi yang dipungut atas perizinan tertentu. Retribusi yang dipungut atas jasa umum menurut Undang-Undang No. 28 Tahun 2009 adalah pengutan daerah sebagai pembayaran atas pelayanan yang disediakan atau diberikan pemerintah daerah untuk tujuan kepentingan dan kemanfaatan umum serta dapat dinikmati oleh orang pribadi atau badan. Tetapi dapat tidak dipungut apabila potensi penerimannya kecil dan/atau atas kebijakan nasional/daerah untuk memberikan pelayanan tersebut secara gratis. Sementara itu, retribusi atas jasa usaha menurut Undang-Undang No. 28 Tahun 2009 adalah pungutan daerah sebagai pembayaran atas pelayanan yang disediakan oleh pemerintah daerah dengan menganut prinsip komersial yang meliputi pelayanan dengan menggunakan/memanfaatkan kekayaan daerah yang belum dimanfaatkan secara optimal dan/atau pelayanan oleh pemerintah daerah sepanjang belum disediakan secara memadai oleh pihak swasta. Sedangkan, retribusi atas perizinan tertentu adalah pungutan daerah atas pembayaran pelayanan perizinan tertentu oleh pemerintah daerah kepada orang pribadi atau badan yang dimaksudkan untuk pengaturan dan pengawasan atas kegiatan pemanfaatan ruang, penggunaan sumber daya alam, barang, prasarana, sarana, atau fasilitas tertentu guna melindungi kepentingan umum dan menjaga kelestarian lingkungan.

\subsection{Hasil Pengelolahan Kekayaan Milik Daerah Yang Dipisahkan}

Hasil pengelolaan kekayaan daerah yang dipisahkan berdasarkan Permendagri No. 59 Tahun 2007 tentang Perubahan Permendagri No. 13 Tahun 2006 menurut objek pendapatan mencakup; bagian laba atas penyertaan modal pada perusahaan milik daerah/BUMD, bagian laba atas penyertaan modal pada perusahaan milik pemerintah/BUMN, dan bagian laba atas penyertaan modal pada perusahaan milik swasta atau kelompok usaha masyarakat.

\subsection{Pendapatan Asli Daerah Lain yang Sah}

Pendapatan asli daerah lainnya yang sah disediakan untuk menganggarkan penerimaan daerah yang tidak termasuk dalam jenis pajak daerah retribusi daerah, dan hasil pengelolaan kekayaan daerah yang dipisahkan dan dirinci menurut obyek pendapatan, antara lain; hasil penjualan kekayaan daerah yang tidak dipisahkan secara tunai atau angsuran/cicilan, jasa giro, pendapatan bunga, penerimaan atas tuntutan ganti kerugian daerah, penerimaan komisi, 
potongan ataupun bentuk lain sebagai akibat dari penjualan dan/atau pengadaan barang dan/atau jasa oleh daerah, penerimaan keuntungan dari selisih nilai tukar rupiah terhadap mata uang asing, pendapatan denda atas keterlambatan pelaksanaan pekerjaan, pendapatan denda pajak, pendapatan denda retribusi, pendapatan hasil eksekusi atas jaminan, pendapatan dari pengembalian, fasilitas sosial dan umum, pendapatan dari penyelenggaraan pendidikan dan pelatihan, dan pendapatan dari badan layanan umum daerah (BLUD).

\section{Metodologi Penelitian}

\subsection{Desain Penelitian}

Penelitian ini adalah penelitian deskriptif dengan pendekatan kuantitatif. Penelitian deskriptif ini bertujuan untuk menjelaskan atau mendiskripsikan suatau keadaan dan peristiwa. Penelitian deskriptif adalah penelitian untuk menganalisa data dengan cara mendeskripsikan atau menggabarkan data yang telah terkumpul sebagaimana adanya tanpa bermaksud membuat kesimpulan yang berlaku untuk umum atau generalisasi (Sugiyono, 2014:206).

\subsection{Lokasi Penelitian}

Penelitian ini dilakukan di seluruh kabupaten/kota di Provinsi Sulawesi Tengah. Obyek penelitian adalah Pendapatan Asli Daerah (PAD), Pajak Daerah, Retribusi Daerah, Hasil Pengelolaan Kekayaan Daerah yang Dipisahkan, dan Pendapatan Asli Daerah Lainnya yang Sah pada Pemerintah Kabupaten/Kota di Provinsi Sulawesi Tengah tahun 2014-2018.

\subsection{Teknik Analisis}

Teknik analisis data yang digunakan adalah dengan melakukan analisis deskriptif atas pertumbuhan dan kontribusi dari setiap komponen PAD. Analisis pertumbuhan atau analisis tren, digunakan untuk mengetahui tingkat pertumbuhan masing-masing jenis pendapatan asli daerah (PAD) dalam suatu periode, formulanya adalah sebagai berikut:

$$
\Delta \mathrm{Xi}=\frac{X i t-X i t(t-1)}{\text { Xit }(t-1)} \times 100 \text { persen }
$$

Dimana:

$\triangle X_{i} \quad$ : Rasio pertumbuhan komponen PAD

$X_{\text {it }} \quad$ : Jumlah setiap komponen PAD tahun ke $t$

$\mathrm{X}_{\text {it (t-1) }} \quad$ : Jumlah setiap komponen PAD PAD tahun ke $\mathrm{t}-1$ 
Selanjutnya, analisis kontribusi dilakukan untuk mengetahui kontribusi setiap komponen PAD dalam setiap periode, formula perhitungannya adalah sebagai berikut.

$$
\Delta \mathrm{Xi}=\frac{\mathrm{Xi}}{\mathrm{X}} \mathrm{x} 100 \text { persen }
$$

Dimana:

$\triangle \mathrm{X}_{\mathrm{i}} \quad$ : Rasio kontribusi komponen PAD

$\mathrm{X}_{\mathrm{i}} \quad$ : Total PAD

Selanjutnya, setelah diketahui masing-masing nilai pertumbuhan dan nilai kontribusi setiap komponen PAD. Kemudian, dilakukan perhitungan untuk mencari nilai rata-rata PAD dan komponennya. Terakhir dilakukan analisis berdasarkan kategori yang telah ditetapkan pada tabel 3.1 di bawah ini. Kedua tabel tersebut diadaptasi dari penelitian sebelumnya lihat (Sartika, Ulfa, \& llyas, 2019).

Tabel 3.1. Tingkat Kategori Pertumbuhan dan Kontribusi PAD

\begin{tabular}{cccc}
\hline $\begin{array}{c}\text { Tingkat } \\
\text { Pertumbuhan }\end{array}$ & Kategori & $\begin{array}{c}\text { Derajat } \\
\text { Kontribusi }\end{array}$ & Kategori \\
\hline $85 \%-100 \%$ & Sangat Berhasil & $>50 \%$ & Sangat Baik \\
$70 \%-85 \%$ & Berhasil & $40 \%-50 \%$ & Baik \\
$55 \%-70 \%$ & Cukup Berhasil & $30 \%-40 \%$ & Sedang \\
$30 \%-55 \%$ & Kurang Berhasil & $20 \%-30 \%$ & Cukup Baik \\
$<30 \%$ & Tidak Berhasil & $10 \%-20 \%$ & Kurang Baik \\
& & $<10 \%$ & Sangat Kurang Baik \\
\hline
\end{tabular}

Sumber: Halim dalam Sartika, et. al. (2018)

\section{Analisis dan Pembahasan}

\section{1. $\quad$ Deskripsi Pertumbuhan Komponen Pendapatan Asli Daerah (PAD)}

Selanjutnya, keberhasilan pemerintah daerah dalam mengelola potensi daerahnya, juga dapat dilihat dari pertumbuhan PAD setiap tahunnya. Jika persentase pertumbuhan PAD terus mengalami kenaikan setiap tahunnya, maka dikatakan bahwa pemerintah daerah tersebut mampu mengelola potensi daerahnya. Jika sebaliknya, terus mengalami penurunan, maka itu salah satu indikasi bahwa pemerintah daerah tidak mampu mengoptimalkan potensi daerahnya. Untuk itu, dilakukan analisis horisontal (tren) untuk mengetahui tingkat pertumbuhan dari setiap komponen $\mathrm{PAD}$, yang terdiri dari pajak daerah, retribusi daerah, pengelolaan kekayaan daerah yang dipisahkan, dan lain-lain pendapatan asli daerah yang sah.

Tabel 4.1. merepresentasikan tingkat pertumbuhan pajak daerah kabupaten/kota di Provinsi Sulawesi Tengah Tahun 2014-2018. Dari tabel tersebut tergambar bahwa tingkat pertumbuhan pajak daerah selama tahun tersebut sebesar 34.17 persen, lebih rinci pada tahun 
2015 adalah rata-rata sebesar 10.25 persen, kemudian pada tahun 2015 tumbuh sebesar 88.17 persen. Namun, pada tahun 2017 juga mengalami pertumbuhan tetapi lebih rendah daripada tahun sebelumnya, yaitu hanya sebesar 16.46 persen, begitupula tahun 2018 tumbuh sebesar 21.81 persen meskipun pertumbuhannya tidak sebesar pada tahun 2016. Dari tabel tersebut juga terlihat bahwa pertumbuhan pajak daerah antar kabupaten/kota di Provinsi Sulawesi Tengah sangat fluktuatif, yakni berkisar antara 2.71 persen dan 132.58 persen. Pertumbuhan pajak daerah tertinggi diraih oleh Kabupaten Morowali sebesar 132.58 persen, diikuti Kabupaten Poso sebesar 114.76 persen, dan terendah diduduki oleh Kabupaten Boul sebesar 2.71 persen, dan Kabupaten Tojo Una-Una sebesar 5.31 persen, serta Kabupaten Morowali Utara 6.39 persen. Dari 13 kabupaten/kota di Provinsi Sulawesi Tengah, hanya tiga Kabupaten/kota yang tingkat pertumbuhan pajak daerahnya di atas nilai rata-rata, yaitu Kabupaten Morowali, Kabupaten Poso, dan Kabupaten Banggai Laut.

Tabel 4.1. Tingkat Pertumbuhan Pajak Daerah Kabupaten/Kota Di Provinsi Sulawesi Tengah Tahun 2014-2018

\begin{tabular}{|c|c|c|c|c|c|c|}
\hline \multirow{2}{*}{$\begin{array}{c}\text { Nama Kabupaten/ } \\
\text { Kota } \\
\end{array}$} & \multicolumn{5}{|c|}{ Pajak Daerah } & \multirow{2}{*}{$\begin{array}{l}\text { Rata } \\
\text { Rata }\end{array}$} \\
\hline & 2014 & 2015 & 2016 & 2017 & 2018 & \\
\hline Kab. Parigi Moutong & 0.00 & 15.07 & 45.06 & 12.56 & -8.59 & 16.03 \\
\hline Kab. Donggala & 0.00 & 8.65 & 2.89 & 18.13 & -0.73 & 7.23 \\
\hline Kab. Sigi & 0.00 & -6.60 & 10.82 & 32.94 & 9.23 & 11.60 \\
\hline Kab. Poso & 0.00 & 68.92 & 412.80 & -68.76 & 46.06 & 114.76 \\
\hline Kab. Tolitoli & 0.00 & 19.06 & 20.94 & 31.73 & 1.97 & 18.43 \\
\hline Kab. Banggai & 0.00 & 4.05 & 11.20 & 35.03 & 18.38 & 17.17 \\
\hline Kab. Banggai Laut & 0.00 & 21.54 & 300.82 & 38.55 & -15.41 & 86.38 \\
\hline Kab. Banggai Kepulauan & 0.00 & -5.06 & 18.16 & 27.11 & -11.47 & 7.18 \\
\hline Kab. Morowali & 0.00 & 68.92 & 192.89 & 36.06 & 232.43 & 132.58 \\
\hline Kab. Morawali Utara & 0.00 & -78.26 & 95.42 & 0.74 & 7.66 & 6.39 \\
\hline Kab. Tojo Una-Una & 0.00 & -5.57 & 10.82 & 25.60 & -9.62 & 5.31 \\
\hline Kab. Buol & 0.00 & -8.93 & 12.72 & -5.54 & 12.58 & 2.71 \\
\hline Kota Palu & 0.00 & 31.41 & 11.63 & 29.82 & 1.10 & 18.49 \\
\hline Rata-rata & $\mathbf{0 . 0 0}$ & 10.25 & 88.17 & 16.46 & 21.81 & 34.17 \\
\hline
\end{tabular}

Sumber: data diolah, 2019

Pada tabel 4.2 di bawah ini dapat dikatakan bahwa rata-rata pertumbuhan retribusi daerah kabupaten/kota di Provinsi Sulawesi Tengah pada tahun 2014-2018 sebesar 26.06 persen. Lebih jauh terlihat bahwa rata-rata pertumbuhan retribusi daerah pada tahun 2015 sebesar 14.82 persen, kemudian pada tahun 2016 tetap tumbuh tetapi tidak sebesar tahun sebelumnya, yaitu hanya sebesar 3.69 persen. Berbeda dengan dua tahun sebelumnya, pada tahun 2017 retribusi daerah mengalami pertumbuhan sebesar 34.86 persen dan pada tahun 2018 sebesar 50.88 persen. Pertumbuhan retribusi daerah antar kabupaten/kota juga terlihat sangat fluktuatif, yaitu kisaran -12.00 persen sampai dengan 187.76 persen. 
Tabel 4.2. Tingkat Pertumbuhan Retribusi Daerah Kabupaten/Kota Di Provinsi Sulawesi Tengah Tahun 2014-2018

\begin{tabular}{|c|c|c|c|c|c|c|}
\hline \multirow{2}{*}{$\begin{array}{c}\text { Nama Kabupaten/ } \\
\text { Kota }\end{array}$} & \multicolumn{5}{|c|}{ Retribusi Daerah } & \multirow{2}{*}{$\begin{array}{l}\text { Rata } \\
\text { Rata }\end{array}$} \\
\hline & 2014 & 2015 & 2016 & 2017 & 2018 & \\
\hline Kab. Parigi Moutong & 0.00 & -19.84 & 26.73 & 17.13 & -30.66 & -1.66 \\
\hline Kab. Donggala & 0.00 & -83.39 & 50.86 & -41.01 & 122.82 & 12.32 \\
\hline Kab. Sigi & 0.00 & 22.41 & -43.54 & 23.44 & 10.30 & 3.15 \\
\hline Kab. Poso & 0.00 & 113.46 & 13.21 & -72.52 & 44.06 & 24.55 \\
\hline Kab. Tolitoli & 0.00 & -84.93 & 22.83 & 6.66 & 7.45 & -12.00 \\
\hline Kab. Banggai & 0.00 & 2.60 & -78.54 & 2.10 & 143.84 & 17.50 \\
\hline Kab. Banggai Laut & 0.00 & 52.76 & 46.79 & 8.97 & 5.66 & 28.55 \\
\hline Kab. Banggai Kepulauan & 0.00 & 65.75 & 63.66 & 88.14 & -2.89 & 53.67 \\
\hline Kab. Morowali & 0.00 & 113.46 & -24.17 & 458.63 & 203.14 & 187.76 \\
\hline Kab. Morawali Utara & 0.00 & -19.82 & 42.38 & 1.31 & 12.71 & 9.15 \\
\hline Kab. Tojo Una-Una & 0.00 & 22.41 & -43.54 & -28.64 & 46.81 & -0.74 \\
\hline Kab. Buol & 0.00 & 8.60 & -23.52 & -0.40 & 74.15 & 14.71 \\
\hline $\begin{array}{l}\text { Kota Palu } \\
\text { Rata-rata }\end{array}$ & $\begin{array}{l}\text { O.OO } \\
\text { 0.00 }\end{array}$ & $\begin{array}{l}-0.86 \\
14.82\end{array}$ & $\begin{array}{r}-5.21 \\
\mathbf{3 . 6 9}\end{array}$ & $\begin{array}{r}-10.58 \\
34.86\end{array}$ & $\begin{array}{l}24.06 \\
50.88\end{array}$ & $\begin{array}{r}1.85 \\
26.06\end{array}$ \\
\hline
\end{tabular}

Sumber: data diolah, 2019

Pertumbuhan retribusi daerah tertinggi diraih oleh Kabupaten Morowali yaitu rata-rata sebesar 187.76 persen, disusul Kabupaten Banggai Kepulauan 53,67 persen, pertumbuhan terendah ditempati oleh Kabupaten Toli-Toli, Kabupaten Parigi Moutong, dan Kabupaten Tojo Una-Una secara berurutan sebesar -12.00 persen, -1,66 persen, dan -0,74 persen. Dari tabel itu, juga terlihat bahwa hanya Kabupaten Banggai Kepulauan dan Kabupaten Morowali yang tingkat pertumbuhan rertribusi daerahnya berada di atas nilai rata-rata.

Tabel 4.3 menggambarkan pertumbuhan pengelolaan kekayaan daerah yang dipisahkan pada kabupaten/kota di Provinsi Sulawesi Tengah Tahun 2014-2018. Tabel tersebut menunjukkan bahwa rata-rata pertumbuhan pengelolaan kekayaan daerah yang dipisahkan selama tahun 2014-2018 sebesar 45.69 persen. Lebih khusus, pada tahun 2015 rata-rata pertumbuhan pengelolaan kekayaan daerah yang dipisahkan sebesar Rp59.82 persen, kemudian pada tahun 2016 mengalami pertumbuhan sebesar 107.43 persen, dan pada tahun 2017 sebesar 8.03 , serta tahun 2018 sebesar 7.47 persen.

Tabel 4.3. Tingkat Pertumbuhan Pengelolaan Kekayaan Daerah yang Dipisahkan pada Kabupaten/Kota di Provinsi Sulawesi Tengah Tahun 2014-2018

\begin{tabular}{|c|c|c|c|c|c|c|}
\hline \multirow{2}{*}{$\begin{array}{l}\text { Nama Kabupaten/ } \\
\text { Kota }\end{array}$} & \multicolumn{5}{|c|}{ Peng. Kekayaan Daerah yang Dipisahkan } & \multirow{2}{*}{$\begin{array}{l}\text { Rata } \\
\text { Rata }\end{array}$} \\
\hline & 2014 & 2015 & 2016 & 2017 & 2018 & \\
\hline Kab. Parigi Moutong & 0.00 & -3.92 & 11.66 & -26.55 & -19.97 & -9.70 \\
\hline Kab. Donggala & O.OO & 115.53 & 22.20 & -21.11 & -17.56 & 24.77 \\
\hline Kab. Sigi & 0.00 & 73.57 & 138.54 & 3.41 & 23.16 & 59.67 \\
\hline Kab. Poso & 0.00 & 121.31 & 896.62 & -84.42 & 0.00 & 233.37 \\
\hline Kab. Tolitoli & 0.00 & 106.83 & 18.70 & -10.99 & 16.30 & 32.71 \\
\hline Kab. Banggai & 0.00 & 101.90 & 22.98 & -15.88 & 3.84 & 28.21 \\
\hline Kab. Banggai Laut & 0.00 & O.OO & O.OO & O.OO & $0.00^{\circ}$ & O.OO \\
\hline Kab. Banggai Kepulauan & 0.00 & 116.29 & 34.46 & 13.64 & -32.01 & 33.09 \\
\hline Kab. Morowali & O.OO & 97.90 & 11.66 & -12.35 & -14.13 & 20.77 \\
\hline Kab. Morawali Utara & O.OO & 0.00 & O.OO & O.OO & 76.68 & 19.17 \\
\hline Kab. Tojo Una-Una & 0.00 & 73.57 & 138.54 & 178.94 & 2.73 & 98.44 \\
\hline Kab. Buol & 0.00 & 33.43 & 35.07 & -13.15 & 58.08 & 28.36 \\
\hline Kota Palu & 0.00 & -58.73 & 66.14 & 92.81 & 0.00 & 25.06 \\
\hline Rata-rata & O.00 & 59.82 & 107.43 & 8.03 & 7.47 & 45.69 \\
\hline
\end{tabular}

Sumber: data diolah, 2019 
Selain itu, juga terlihat bahwa rata-rata pertumbuhan pengelolaan kekayaan daerah yang dipisahkan antar kabupaten/kota di Provinsi Sulawesi Tengah selama empat tahun sangat bervariasi mulai dari -9.70 persen sampai dengan 233.37 persen. Terlihat juga, bahwa terdapat tiga kabupaten/kota yang tingkat pertumbuhaanya pengelolaan kekayaan daerah berada di atas nilai rata-rata, yaitu Kabupaten Poso, Kabupaten Tojo Una-una dan Kabupaten Poso.

Tabel 4.4. Tingkat Pertumbuhan Lain-lain PAD yang Sah pada Kabupaten/Kota Di Provinsi Sulawesi Tengah Tahun 2014-2018

\begin{tabular}{|c|c|c|c|c|c|c|}
\hline \multirow{2}{*}{$\begin{array}{l}\text { Nama Kabupaten/ } \\
\text { Kota }\end{array}$} & \multicolumn{5}{|c|}{ Lain-lain PAD yang Sah } & \multirow{2}{*}{$\begin{array}{l}\text { Rata } \\
\text { Rata }\end{array}$} \\
\hline & 2014 & 2015 & 2016 & 2017 & 2018 & \\
\hline Kab. Parigi Moutong & 0.00 & 2.25 & 12.10 & 87.53 & -38.22 & 15.91 \\
\hline Kab. Donggala & 0.00 & 55.35 & 26.98 & 103.24 & -61.86 & 30.93 \\
\hline Kab. Sigi & 0.00 & $12.08^{\circ}$ & 339.95 & 187.14 & -4.18 & 133.75 \\
\hline Kab. Poso & 0.00 & 402.63 & -98.45 & 13800.12 & -39.06 & 3516.31 \\
\hline Kab. Tolitoli & 0.00 & 156.02 & -5.58 & 71.59 & 11.78 & 58.45 \\
\hline Kab. Banggai & 0.00 & 93.63 & 202.14 & 45.45 & -47.79 & 73.36 \\
\hline Kab. Banggai Laut & 0.00 & 3702.39 & 327.40 & 85.27 & -64.17 & 1012.72 \\
\hline Kab. Banggai Kepulauan & 0.00 & 37.56 & -25.72 & 165.36 & -67.61 & 27.40 \\
\hline Kab. Morowali & 0.00 & 305.30 & -35.26 & 98.24 & 315.12 & 170.85 \\
\hline Kab. Morawali Utara & 0.00 & -8.01 & 185.54 & 135.38 & -43.39 & 67.38 \\
\hline Kab. Tojo Una-Una & 0.00 & 12.08 & 53.22 & 184.24 & -40.09 & 52.36 \\
\hline Kab. Buol & 0.00 & 44.83 & 19.22 & 56.86 & -13.76 & 26.79 \\
\hline Kota Palu & 0.00 & 101.77 & 29.57 & 3.07 & -3.81 & 32.65 \\
\hline Rata-rata & $\mathbf{0 . 0 0}$ & $\mathbf{3 7 8 . 3 0}$ & 79.32 & 1155.65 & -7.47 & 401.45 \\
\hline
\end{tabular}

Dari tabel 4.4 di atas terlihat bahwa rata-rata pertumbuhan lain-lain PAD yang sah kabupaten/kota di Provinsi Sulawesi selama empat tahun sebesar 401.45 persen. Tabel tersebut menjelaskan bahwa Kabupaten Poso memiliki nilai pertumbuhan lain-lain PAD yang tertinggi yaitu sebesar 3516.31 persen, disusul Kabupaten Banggai Laut sebesar 1012.72 persen, dan nilai terendah didapatkan oleh Kabupaten Parigi Moutong sebesar 15.91 persen, diikuti Kabupaten Boul dan Kabupaten Banggai Laut secara berurutan sebesar 26.79 persen dan 27.40 persen. Disisi lain, dari tabel itu juga memperlihatkan bahwa pertumbuhan penerimaan lain-lain pendapatan asli daerah yang sah tertinggi pada tahun 2017 sebesar 1155.65 persen, dan terendah pada tahun 2018 sebesar -7.47 persen. Dari tabel tersebut juga menunjukkan bahwa hanya Kabupaten Poso dan Kabupaten Banggai Laut yang memiliki tingkat pertumbuhan lain-lain PAD yang sah di atas nilai rata-rata.

Tabel 4.5 memperlihatkan secara keseluruhan pertumbuhan pendapatan asli daerah (PAD) pada kabupaten/kota di Provinsi Sulawesi Tengah pada tahun 2014-2018. Tabel tersebut menunjukkan rata-rata pertumbuhan PAD kabupaten/kota di Provinsi Sulawesi Tengah pada tahun 2015 sebesar 48.83 persen, pada tahun 2016 sebesar 117.74 persen, pada tahun 2017 sebesar 159.17 persen, dan pada tahun 2018 sebesar -7.13 persen. Sementara rata-rata pertumbuhan PAD selama empat tahun itu sebesar 79.65 persen. Di sisi lain, terlihat bahwa pertumbuhan PAD kabupaten/kota di Provinsi Sulawesi Tengah selama lima tahun tertinggi 
sebesar 304.67 persen ditempati oleh Kabupaten Poso, disusul Kabupaten Banggai sebesar 304.67 persen dan terendah diduduki oleh Kabupaten Donggala sebesar 9.98 persen dan Kabupaten Parigi Moutong sebesar 13.23 persen. Dari tabel tersebut terlihat bahwa sebagian besar kabupaten/kota di Provinsi Sulawesi Tengah memiliki tingkat pertumbuhan di bawah nilai rata-rata. Hal ini terlihat dari 13 kabupaten/kota, hanya tiga kabupaten/kota yang tingkat pertumbuhannya di atas nilai rata-rata yaitu Kabupaten Poso, Kabupaten Banggai, dan Kabupaten Morowali.

Tabel 4.5. Tingkat Pertumbuhan Pendapatan Asli Daerah (PAD) Kabupaten/Kota Di Provinsi Sulawesi Tengah Tahun 2014-2018

\begin{tabular}{|c|c|c|c|c|c|c|}
\hline \multirow{2}{*}{$\begin{array}{c}\text { Nama Kabupaten/ } \\
\text { Kota }\end{array}$} & \multicolumn{5}{|c|}{ Pendapatan Asli Daerah } & \multirow{2}{*}{$\begin{array}{l}\text { Rata } \\
\text { Rata }\end{array}$} \\
\hline & 2014 & 2015 & 2016 & 2017 & 2018 & \\
\hline Kab. Parigi Moutong & O.OO & 1.67 & 17.14 & 68.76 & -34.66 & 13.23 \\
\hline Kab. Donggala & 0.00 & 2.94 & 18.28 & 60.45 & -41.76 & 9.98 \\
\hline Kab. Sigi & O.OO & 8.13 & 28.21 & 134.25 & -1.53 & 42.26 \\
\hline Kab. Poso & O.OO & 193.75 & 1140.87 & -88.05 & -21.04 & 306.38 \\
\hline Kab. Tolitoli & 0.00 & 32.93 & 0.04 & 57.98 & 10.48 & 25.36 \\
\hline Kab. Banggai & O.OO & 18.75 & 20.35 & 1271.51 & -91.91 & 304.67 \\
\hline Kab. Banggai Laut & O.OO & 109.34 & 166.90 & 53.00 & -40.57 & 72.17 \\
\hline Kab. Banggai Kepulauan & 0.00 & 29.82 & -9.18 & 116.29 & -51.03 & 21.48 \\
\hline Kab. Morowali & O.OO & 193.75 & -2.21 & 161.79 & 236.60 & 147.48 \\
\hline Kab. Morawali Utara & 0.00 & -50.83 & 86.03 & 46.77 & -17.10 & 16.22 \\
\hline Kab. Tojo Una-Una & 0.00 & 8.13 & 28.21 & 131.40 & -33.06 & 33.67 \\
\hline Kab. Buol & O.OO & 30.97 & 15.82 & 43.11 & -6.75 & 20.79 \\
\hline Kota Palu & O.OO & 55.49 & 20.21 & 11.97 & -0.40 & 21.82 \\
\hline Rata-rata & O.00 & 48.83 & 117.74 & 159.17 & -7.13 & 79.65 \\
\hline
\end{tabular}

\section{2. $\quad$ Deskripsi Kontribusi Komponen Pendapatan Asli Daerah (PAD)}

Selanjutnya, persentase tingkat kontribusi PAD yang tinggi mengisyaratkan pemerintah daerah mampu mengelola potensi daerahnya untuk membiayai penyelenggaraan pemerintahan. Sebaliknya, persentase tingkat kontribusi PAD yang kecil menandakan pemerintah daerah tersebut belum mampu mengelola potensi daerahnya. Bagian ini memaparkan kontribusi dari setiap komponen pendapatan asli daerah (PAD) terhadap PAD, dan kontribusi PAD terhadap pendapatan daerah kabupaten/kota di Provinsi Sulawesi Tengah pada tahun 2014-2018.

Pada tabel 4.6 di bawah ini tergambar bahwa rata-rata kontribusi pajak daerah terhadap Pendapatan Asli Daerah (PAD) kabupaten/kota di Provinsi Sulawesi Tengah tahun 2014-2018 adalah sebesar 22.41 persen. Dari tabel itu pula terlihat pada tahun 2014 kontribusi pajak daerah terhadap PAD kabupaten/kota di Provinsi Sulawesi Tengah sebesar 28.22 persen, pada tahun 2015 sebesar 21.45 persen, tahun 2016 sebesar 22.85 persen, tahun 2017 sebesar 16.00 persen, dan tahun 2018 sebesar 23.51 persen. Dari sisi kontribusi pajak daerah terhadap PAD antar kabupaten/kota di Provinsi Sulawesi Tengah selama lima tahun cukup seragam yaitu antara 12.64 sampai dengan 39.53 persen. Kontribusi pajak daerah terhadap PAD tertinggi 
dipegang oleh Kota Palu sebesar 39.53 persen, diikuti oleh Kabupaten Donggala sebesar 35.82 persen, dan kontribusi terendah di diduduki oleh Kabupaten Parigi Moutong sebesar 12.64 persen, Kabupaten Boul 12.85 persen, dan Kabupaten Toli-Toli sebesar 13.15 persen. Selain itu dari 13 kabupaten/kota di Provinsi Sulawesi Tengah, terdapat enam kabupaten/kota yang tingkat kontribusinya di atas nilai rata-rata, yaitu Kota Palu, Kabupaten Donggala, Kabupaten Morowali Utara, Kabupaten Banggai, Kabupaten Tojo Una-Una, dan Kabupaten Sigi.

Tabel 4.6. Tingkat Kontribusi Pajak Daerah Terhadap PAD Kabupaten/Kota Di Provinsi Sulawesi Tengah Tahun 2014-2018

\begin{tabular}{|c|c|c|c|c|c|c|}
\hline \multirow{2}{*}{$\begin{array}{l}\text { Nama Kabupaten/ } \\
\text { Kota }\end{array}$} & \multicolumn{5}{|c|}{ Pajak Daerah } & \multirow{2}{*}{$\begin{array}{l}\text { Rata } \\
\text { Rata }\end{array}$} \\
\hline & 2014 & 2015 & 2016 & 2017 & 2018 & \\
\hline Kab. Parigi Moutong & 10.94 & 12.38 & 15.34 & 10.23 & 14.31 & 12.64 \\
\hline Kab. Donggala & 37.30 & 39.37 & 34.24 & 25.21 & 42.97 & 35.82 \\
\hline Kab. Sigi & 33.04 & 28.54 & 24.67 & 14.00 & 15.53 & 23.15 \\
\hline Kab. Poso & 21.62 & 12.43 & 5.14 & 13.43 & 24.85 & 15.49 \\
\hline Kab. Tolitoli & 13.95 & 12.49 & 15.10 & 12.59 & 11.62 & 13.15 \\
\hline Kab. Banggai & 30.59 & 26.80 & 24.77 & 2.44 & 35.70 & 24.06 \\
\hline Kab. Banggai Laut & 21.51 & 12.49 & 18.75 & 16.98 & 24.17 & 18.78 \\
\hline Kab. Banggai Kepulauan & 24.87 & 18.19 & 23.66 & 13.91 & 25.14 & 21.15 \\
\hline Kab. Morowali & 21.62 & 12.43 & 37.23 & 19.35 & 19.11 & 21.95 \\
\hline Kab. Morawali Utara & 55.37 & 24.48 & 25.71 & 17.65 & 22.92 & 29.22 \\
\hline Kab. Tojo Una-Una & 32.68 & 28.54 & 24.67 & 13.39 & 18.08 & 23.47 \\
\hline Kab. Buol & 19.13 & 13.30 & 12.95 & 8.55 & 10.32 & 12.85 \\
\hline Kota Palu & 44.29 & 37.43 & 34.76 & 40.30 & 40.90 & 39.53 \\
\hline Rata-rata & 28.22 & 21.45 & 22.85 & 16.00 & 23.51 & 22.41 \\
\hline
\end{tabular}

Sumber: data diolah, 2019

Kemudian, pada tabel 4.7 di bawah ini memberitahukan bahwa pada tahun 2014 tingkat kontribusi retribusi daerah terhadap pendapatan asli daerah (PAD) kabupaten/kota di Provinsi Sulawesi Tengah sebesar 29.30 persen, tahun 2015 sebesar 22.11 persen, tahun 2016 sebesar 12.68 persen, tahun 2017 sebesar 11.40 persen, dan pada tahun 2018 sebesar 16.79 persen. Dengan demikian, secara rata-rata kontribusi retribusi daerah terhadap PAD kabupaten/kota di Provinsi Sulawesi Tengah selama lima tahun (2014-2018) adalah sebesar 18.46 persen.

Disisi lain, juga terlihat bahwa kontribusi antar kabupaten/kota di Provinsi Sulawesi Tengah tahun 2014-2018 tertinggi ditempati oleh Kabupaten Banggai Laut sebesar 44.91 persen, dan diikuti oleh Kabupaten Morowali sebesar 40.44 persen. Kemudian, kontribusi terendah dijabat oleh Kabupaten Boul sebesar 6.08 persen, dan Kabupaten Parigi Moutong sebesar 6.45 persen. Tabel tersebut juga menunjukkan bahwa masih terdapat delapan kabupaten/kota yang tingkat kontribusi retribusi daerahnya terhadap PAD dibawah nilai ratarata, yaitu Kabupaten Boul, Kabupaten Parigi Moutong, Kota Palu, Kabupaten Tojo Una-Una, Kabupaten Sigi, Kabupaten Donggala, Kabupaten Banggai Kepulauan, dan Kabupaten Tolitoli. 
Tabel 4.7. Tingkat Kontribusi Retribusi Daerah Terhadap PAD Kabupaten/Kota Di Provinsi Sulawesi Tengah Tahun 2014-2018

\begin{tabular}{|c|c|c|c|c|c|c|}
\hline \multirow{2}{*}{$\begin{array}{c}\text { Nama Kabupaten/ } \\
\text { Kota }\end{array}$} & \multicolumn{5}{|c|}{ Retribusi Daerah } & \multirow{2}{*}{$\begin{array}{l}\text { Rata } \\
\text { Rata }\end{array}$} \\
\hline & 2014 & 2015 & 2016 & 2017 & 2018 & \\
\hline Kab. Parigi Moutong & 8.35 & 6.59 & 7.12 & 4.95 & 5.25 & 6.45 \\
\hline Kab. Donggala & 26.17 & 4.22 & 5.38 & 1.98 & 7.57 & 9.07 \\
\hline Kab. Sigi & 12.79 & 14.48 & 6.38 & 3.36 & 3.76 & 8.16 \\
\hline Kab. Poso & 4.19 & 32.11 & 2.93 & 6.74 & 12.30 & 65 \\
\hline Kab. Tolitoli & 42.66 & 4.84 & 5.94 & 4.01 & 3.90 & 12.27 \\
\hline Kab. Banggai & 52.27 & 45.16 & 8.05 & 0.60 & 18.08 & 24.83 \\
\hline Kab. Banggai Laut & 76.76 & & 30.81 & 21.94 & 39 & 91 \\
\hline Kab. Banggai Kepulauan & 6.28 & 8.01 & 14.44 & .56 & 24 & 3.24 \\
\hline Kab. Morowali & 44.19 & .11 & 24.90 & .13 & 47.85 & .44 \\
\hline Kab. Morawali Utara & 33.18 & 54.10 & 41.41 & 28.58 & 38.86 & 39.23 \\
\hline Kab. Tojo Una-Una & 12.79 & 14.48 & 6.38 & 1.97 & 4.31 & 7.99 \\
\hline Kab. Buol & 8.77 & 7.27 & 4.80 & 3.34 & 6.24 & 6.08 \\
\hline Kota Palu & 12.54 & 7.99 & 6.30 & 5.03 & 6.27 & 7.63 \\
\hline Rata-rata & 29.30 & 22.11 & 12.68 & 11.40 & 16.79 & 18.46 \\
\hline
\end{tabular}

Sumber: data diolah, 2019

Tabel 4.8 di bawah ini menunjukkan tingkat kontribusi pengelolaan kekayaan daerah yang dipisahkan terhadap pendapatan asli daerah (PAD) kabupaten/kota di Provinsi Sulawesi Tengah tahun 2014-2018. Dari tabel tersebut terlihat bahwa rata-rata tingkat kontribusi pengelolaan kekayaan daerah yang dipisahkan selama lima tahun adalah sebesar 11.45 persen. Tingkat kontribusi pengelolaan kekayaan daerah yang dipisahkan terendah pada tahun 2014 sebesar 8.52 persen, dan tertinggi pada tahun 2015 sebesar 11.93 persen. Selanjutnya, kontribusi pengelolaan kekayaan daerah yang dipisahkan antar kabupaten/kota tertinggi dipegang oleh Kabupaten Boul sebesar 29.73 persen, disusul Kabupaten Tolitoli sebesar 24.26 persen, sedangkan kontribusi terendah ditempati oleh Kabupaten Banggai Laut sebesar 0.00 persen, dan Kota Palu sebesar 2.02 persen. Dari tabel tersebut juga terlihat bahwa hanya lima Kabupaten yang tingkat kontribusi pengelolaan kekayaan daerah yang dipisahkan terhadap PAD berada di atas nilai rata-rata yaitu Kabupaten Boul, Kabupaten Tolitoli, Kabupaten Poso, Kabupaten Parigi Moutong dan Kabupaten Tojo Una-una.

Tabel 4.8 Tingkat Kontribusi Pengelolaan Kekayaan Daerah yang Dipisahkan Terhadap PAD Kabupaten/Kota Di Provinsi Sulawesi Tengah Tahun 2014-2018

\begin{tabular}{|c|c|c|c|c|c|c|}
\hline $\begin{array}{l}\text { Nama Kabupaten/ } \\
\text { Kota }\end{array}$ & $\begin{array}{l}\text { Peng } \\
2014\end{array}$ & \multicolumn{4}{|c|}{ Kekda yang Dipisahkan } & $\begin{array}{l}\text { Rata } \\
\text { Rata }\end{array}$ \\
\hline Kab. Parigi Moutong & 20.04 & 16.73 & 12.88 & 8.40 & 7.36 & 13.08 \\
\hline Kab. Donggala & 5.87 & 11.63 & 13.82 & 9.23 & 7.66 & 9.64 \\
\hline Kab. Sigi & 2.43 & 4.52 & 9.73 & 7.57 & 8.54 & 6.56 \\
\hline Kab. Poso & 14.72 & 19.29 & 37.48 & 18.69 & 12.79 & 20.59 \\
\hline Kab. Tolitoli & 17.56 & 30.50 & 29.93 & 20.23 & 23.07 & 24.26 \\
\hline Kab. Banggai & 4.14 & 8.03 & 8.88 & 5.54 & 4.86 & 6.29 \\
\hline Kab. Banggai Laut & O.OO & O.OO & O.OO & O.OO & O.OO & O.OO \\
\hline Kab. Banggai Kepulauan & 5.59 & 12.73 & 14.48 & 12.95 & 9.94 & 11.14 \\
\hline Kab. Morowali & 16.46 & 19.29 & 7.35 & 4.74 & 1.22 & 9.81 \\
\hline Kab. Morawali Utara & O.OO & O.OO & O.OO & 5.87 & 9.64 & 3.10 \\
\hline Kab. Tojo Una-Una & 2.46 & 4.52 & 9.73 & 21.62 & 24.57 & 12.58 \\
\hline Kab. Buol & 18.35 & 26.88 & 32.21 & 29.61 & 41.58 & 29.73 \\
\hline Kota Palu & 3.19 & $1 . \mathrm{OO}$ & 1.49 & 2.21 & 2.19 & 2.02 \\
\hline Rata- & 8.52 & 11.93 & 13.69 & 11.28 & 11.80 & 11.45 \\
\hline
\end{tabular}

Sumber: data diolah, 2019 
Tabel 4.9 di bawah ini mengungkapkan kontribusi lain-lain pendapatan asli daerah yang sah terhadap pendapatan asli daerah (PAD) kabupaten/kota di Provinsi Sulawesi Tengah selama tahun 2014-2018. Dari tabel tersebut tertera bahwa rata-rata kontribusi lain-lain PAD yang sah selama lima tahun itu sebesar 56.45 persen. Kemudian, lebih rinci pada tahun 2014 sebesar 41.34 persen, tahun 2015 sebesar 54.42 persen, tahun 2016 sebesar 64.75 persen, tahun 2017 sebesar 64.18 persen, dan tahun 2018 sebesar 57.56 persen kontribusi dari lainlain PAD terhadap PAD kabupaten/kota di Provinsi Sulawesi Tengah. Tingkat kontribusi tertinggi ditempati oleh Kabupaten Sigi sebesar 92.30 persen, dan terendah Kabupaten Morowali Utara sebesar 30.90 persen, disusul Kabupaten Banggai sebesar 31.62 persen, dan Kabupaten Banggai Laut sebesar 31.62 persen. Terdapat enam kabupaten dari 13 Kabupaten/kota di Provinsi Sulawesi Tengah, yang memiliki tingkat kontribusi berada di atas nilai rata-rata, yaitu Kabupaten Sigi, Kabupaten Boul, Kabupaten Tolitoli, Kabupaten Banggai Kepulauan, dan Kabupaten Tojo Una-una.

Tabel 4.10 di bawah ini memperlihatkan tingkat kontribusi pendapatan asli daerah (PAD) terhadap pendapatan daerah kabupaten/kota di Provinsi Sulawesi Tengah tahun 2014-2018.

Tabel 4.10. Tingkat Kontribusi PAD Terhadap Pendapatan Daerah Kabupaten/Kota Di Provinsi Sulawesi Tengah Tahun 2014-2018

\begin{tabular}{|c|c|c|c|c|c|c|}
\hline \multirow{2}{*}{$\begin{array}{l}\text { Nama Kabupate n/ } \\
\text { Kota }\end{array}$} & \multicolumn{3}{|c|}{ Pendapatan Asli } & \multicolumn{2}{|c|}{ Daerah } & \multirow{2}{*}{$\begin{array}{l}\text { Rata } \\
\text { Rata }\end{array}$} \\
\hline & 2014 & 2015 & 2016 & 2017 & 2018 & \\
\hline Kab. Parigi Moutong & 7.86 & 6.66 & 6.21 & 10.62 & 6.95 & 7.66 \\
\hline Kab. Donggala & 6.81 & 5.52 & 5.60 & 10.01 & 5.62 & 6.71 \\
\hline Kab. Sigi & 3.10 & 2.73 & 2.70 & 6.98 & 6.53 & 4.41 \\
\hline Kab. Poso & 5.35 & 8.91 & 100.00 & 8.57 & 6.65 & 25.90 \\
\hline Kab. Tolitoli & 6.42 & 7.35 & 6.88 & 9.08 & 10.55 & 8.05 \\
\hline Kab. Banggai & 7.89 & 8.14 & 8.13 & 10.06 & 7.52 & 8.35 \\
\hline Kab. Banggai Laut & 1.76 & 1.70 & 3.60 & 4.90 & 2.94 & 2.98 \\
\hline Kab. Banggai Kepulauan & 3.29 & 3.43 & 2.68 & 5.34 & 2.46 & 3.44 \\
\hline Kab. Morowali & 2.83 & 8.91 & 7.70 & 16.65 & 40.12 & 15.24 \\
\hline Kab. Morawali Utara & 7.87 & 2.94 & 4.28 & 6.14 & 4.51 & 5.15 \\
\hline Kab. Tojo Una-Una & 3.10 & 2.73 & 2.70 & 7.87 & 5.03 & 4.29 \\
\hline Kab. Buol & 5.60 & 5.51 & 5.90 & 8.12 & 7.22 & 6.47 \\
\hline Kota Palu & 13.61 & 18.03 & 19.18 & 21.21 & 20.96 & 18.60 \\
\hline Rata-rata & 5.81 & 6.35 & 13.50 & 9.66 & 9.77 & 9.02 \\
\hline
\end{tabular}

\begin{tabular}{llllllll} 
Rata-rata & 41.35 & 54.42 & 64.75 & 64.18 & 57.56 & 56.45 \\
\hline
\end{tabular} Sumber: data diolah, 2019

Didalam tabel tersebut tertera rata-rata tingkat kontribusi PAD terhadap pendapatan daerah selama lima tahun itu adalah sebesar 9.02 persen. Kemudian, kontribusi PAD pada tahun 2014 sebesar 5.81 persen, tahun 2015 sebesar 6.35 persen, tahun 2016 sebesar 13.50 persen, tahun 2017 sebesar 9.66 persen, dan tahun 2018 sebesar 9.77 persen. Sedangkan tingkat kontribusi antar kabupaten/kota, tertinggi Kabupaten Poso sebesar 25.9 persen, dan terendah Kabupaten Banggai Laut sebesar 2.98 persen, disusul Kabupaten Banggai Kepulauan sebesar 3.44 persen. Dari tabel itu pula terlihat bahwa terdapat tiga kabupaten/kota yang memiliki 
tingkat kontribusi PAD terhadap pendapatan daerah di atas nilai rata-rata, yaitu Kabupaten Poso, Kota Palu, dan Kabupaten Morowali.

\subsection{Pembahasan}

Pendapatan asli daerah (PAD) adalah penerimaan daerah yang bersumber dari pengelolaan kekayaan daerah sendiri yang ditetapkan berdasarkan peraturan daerah dan peraturan-peraturan perundangan-undangan. PAD bersumber dari empat jenis yaitu, pajak daerah, retribusi daerah, pengelolaan kekayaan daerah yang dipisahkan, dan lain-lain pendapatan asli daerah yang sah. Tiga tabel di bawah ini menampilkan kriteria pertumbuhan komponen PAD dan kontribusinya terhadap PAD, serta kategori pertumbuhan PAD dan Kontribusi PAD terhadap pendapatan daerah kabupaten/kota di Provinsi Sulawesi Tengah.

Tabel 4.11 di bawah ini menunjukkan tentang kriteria pertumbuhan komponen pendapatan asli daerah (PAD) kabupaten/kota di Provinsi Sulawesi Tengah selama tahun 2014-2018. Merujuk pada tabel tersebut, dapat dijelaskan bahwa mayoritas kabupaten/kota di Provinsi Sulawesi Tengah tidak berhasil dalam meningkatkan penerimaan dari pajak daerah. Hal ini dapat dilihat dari 13 kabupaten/kota di Provinsi Sulawesi Tengah terdapat tiga kabupaten yang tingkat pertumbuhan pajak daerahnya termasuk dalam kualifikasi sangat berhasil, yaitu Kabupaten Poso, Kabupaten Banggai Laut, dan Kabupaten Morowali. Sedangkan sisanya, termasuk dalam kualifikasi tidak berhasil dalam meningkatkan penerimaan pajak daerahnya.

Tabel 4.11. Kriteria Tingkat Pertumbuhan Komponen PAD Kabupaten/Kota Di Provinsi Sulawesi Tengah Tahun 2014-2018

\begin{tabular}{lcccccccc}
\hline \multicolumn{1}{c}{\begin{tabular}{c} 
Nama Kabupaten/ \\
\multicolumn{1}{c}{ Kota }
\end{tabular}} & PD & Kriteria & RD & Kriteria & PKDYD & Kriteria & LPADYS & Kriteria \\
\hline Kab. Parigi Moutong & 16,03 & Tidak Berhasil & $-1,66$ & Tidak Berhasil & $-9,70$ & Tidak Berhasil & 15,91 & Sangat Berhasil \\
Kab. Donggala & 7,23 & Tidak Berhasil & 12,32 & Tidak Berhasil & 24,77 & Tidak Berhasil & 30,93 & Kurang Berhasil \\
Kab. Sigi & 11,60 & Tidak Berhasil & 3,15 & Tidak Berhasil & 59,67 & Cukup Berhasil & 133,75 & Sangat Berhasil \\
Kab. Poso & 114,76 & Sangat Berhasil & 24,55 & Tidak Berhasil & 233,37 & Sangat Berhasil & 3516,31 & Sangat Berhasil \\
Kab. Tolitoli & 18,43 & Tidak Berhasil & $-12,00$ & Tidak Berhasil & 32,71 & Kurang Berhasi & 58,45 & Cukup Berhasil \\
Kab. Banggai & 17,17 & Tidak Berhasil & 17,50 & Tidak Berhasil & 28,21 & Tidak Berhasil & 73,36 & Berhasil \\
Kab. Banggai Laut & 86,38 & Sangat Berhasil & 28,55 & Tidak Berhasil & 0,00 & Tidak Berhasil & 1012,72 & Sangat Berhasil \\
Kab. Banggai Kepulauan & 7,18 & Tidak Berhasil & 53,67 & Kurang Berhasil & 33,09 & Kurang Berhasi & 27,40 & Tidak Berhasil \\
Kab. Morowali & 132,58 & Sangat Berhasil & 187,76 & Sangat Berhasil & 20,77 & Tidak Berhasil & 170,85 & Sangat Berhasil \\
Kab. Morawali Utara & 6,39 & Tidak Berhasil & 9,15 & Tidak Berhasil & 19,17 & Tidak Berhasil & 67,38 & Cukup Berhasil \\
Kab. Tojo Una-Una & 5,31 & Tidak Berhasil & $-0,74$ & Tidak Berhasil & 98,44 & Sangat Berhasil & 52,36 & Kurang Berhasil \\
Kab. Buol & 2,71 & Tidak Berhasil & 14,71 & Tidak Berhasil & 28,36 & Tidak Berhasil & 26,79 & Tidak Berhasil \\
Kota Palu & 18,49 & Tidak Berhasil & 1,85 & Tidak Berhasil & 25,06 & Kurang Berhasi & 32,65 & Kurang Berhasil \\
Sumber: data diolah, 2019 & & & \multicolumn{7}{c}{. } & & & & &
\end{tabular}

Kemudian, dari tabel 4.11 tersebut juga terlihat bahwa mayoritas kabupaten/kota di Provinsi Sulawesi Tengah selama lima tahun (2014-2018) juga tidak berhasil dalam meningkatkan pertumbuhan penerimaan retribusi daerahnya. Hal ini tercermin dari 13 
kabupaten/kota di Provinsi Sulawesi Tengah, hanya satu kabupaten yaitu Kabupaten Morowali yang termasuk dalam kualifikasi sangat berhasil dalam meningkatkan pertumbuhan retribusi daeranya. Juga, terdapat satu kabupaten yang termasuk dalam kualifikasi kurang berhasil, yaitu Kabupaten Banggai Kepulauan. Sementara sisanya, 11 kabupaten/kota dinyatakan tidak berhasil (gagal) meningkatkan penerimaan retribusi daerahnya.

Selain itu, tabel 4.11 tersebut menunjukkan bahwa dari 13 kabupaten/kota di Provinsi Sulawesi Tengah selama tahun 2014-2018, hanya terdapat dua kabupaten/kota yang termasuk dalam kualifikasi sangat berhasil dalam meningkatkan pertumbuhan pengelolaan kekayaan daerah yang dipisahkan, yaitu Kabupaten Poso dan Kabupaten Tojo Una-Una. Satu kabupaten/kota termasuk dalam kualifikasi cukup berhasil yaitu Kabupaten Sigi. Kemudian, terdapat tiga kabupaten termasuk dalam kualifikasi kurang berhasil yaitu Kota Palu, Kabupaten Banggai Kepulauan, dan Kabupaten Tolitoli sedangkan 8 kabupaten/kota lainnya termasuk dalam kualifikasi tidak berhasil meningkatkan pertumbuhan penerimaan pengelolaan kekayaan daerah yang dipisahkan.

Berdasarkan tabel 4.11 di atas juga terlihat bahwa sebanyak lima kabupaten/kota yang tergolong sangat berhasil meningkatkan pertumbuhan lain-lain pendapatan asli daerah yang sah, yaitu Kabupaten Parigi Moutong, Kabupaten Sigi, Kabupaten Poso, Kabupaten Banggai Laut dan Kabupaten Marowali. Dan, Satu kabupaten/kota yang termasuk dalam kualifikasi berhasil yaitu Kabupaten Banggai, dua kabupaten/kota yang tergolong dalam kualifikasi cukup berhasil, yaitu Kabupaten Tolitoli dan Kabupaten Morowali Utara. Sementara sisanya termasuk dalam kategori kurang berhasil, yaitu Kota Palu, Kabupaten Donggala, Kabupaten Tojo Unauna dan tidak berhasil, yaitu Kabupaten Boul dan Kabupaten Banggai Kepulauan.

Tabel 4.12. Kriteria Tingkat Kontribusi Komponen Pendapatan Asli Daerah (PAD) terhadap PAD Kabupaten/Kota Di Provinsi Sulawesi Tengah Tahun 2014-2018

\begin{tabular}{|c|c|c|c|c|c|c|c|c|}
\hline \multirow{2}{*}{$\begin{array}{c}\text { Nama Kabupaten/ } \\
\text { Kota }\end{array}$} & \multicolumn{8}{|c|}{ Komponen Pendapatan Asli Daerah } \\
\hline & PD & Kriteria & RD & Kriteria & PKDYD & Kriteria & LPADYS & Kriteria \\
\hline Kab. Parigi Moutong & 12,64 & Kurang Baik & 6,45 & Sangat Kurang Baik & 13,08 & Kurang Baik & 79,28 & Sangat Baik \\
\hline Kab. Donggala & 35,82 & Sedang & 9,07 & Sangat Kurang Baik & 9,64 & Sangat Kurang Baik & 51,69 & Sangat Baik \\
\hline Kab. Sigi & 23,15 & Cukup Baik & 8,16 & Sangat Kurang Baik & 6,56 & Sangat Kurang Baik & 92,30 & Sangat Baik \\
\hline Kab. Poso & 15,49 & Kurang Baik & 19,65 & Kurang Baik & 20,59 & Cukup Baik & 44,22 & Baik \\
\hline Kab. Tolitoli & 13,15 & Kurang Baik & 12,27 & Kurang Baik & 24,26 & Cukup Baik & 71,38 & Sangat Baik \\
\hline Kab. Banggai & 24,06 & Cukup Baik & 24,83 & Cukup Baik & 6,29 & Sangat Kurang Baik & 31,62 & Sedang \\
\hline Kab. Banggai Laut & 18,78 & Kurang Baik & 44,91 & Baik & 0,00 & Sangat Kurang Baik & 36,31 & Sedang \\
\hline Kab. Banggai Kepulauan & 21,15 & Cukup Baik & 13,24 & Kurang Baik & 11,14 & Kurang Baik & 63,32 & Sangat Baik \\
\hline Kab. Morowali & 21,95 & Cukup Baik & 40,44 & Baik & 9,81 & Sangat Kurang Baik & 37,21 & Sedang \\
\hline Kab. Morawali Utara & 29,22 & Cukup Baik & 39,23 & Sedang & 3,10 & Sangat Kurang Baik & 30,90 & Sedang \\
\hline Kab. Tojo Una-Una & 23,47 & Cukup Baik & 7,99 & Sangat Kurang Baik & 12,58 & Kurang Baik & 66,18 & Sangat Baik \\
\hline Kab. Buol & 12,85 & Kurang Baik & 6,08 & Sangat Kurang Baik & 29,73 & Cukup Baik & 77,45 & Sangat Baik \\
\hline Kota Palu & 39,53 & Sedang & 7,63 & Sangat Kurang Baik & 2,02 & Sangat Kurang Baik & 52,02 & Sangat Baik \\
\hline
\end{tabular}

Selanjutnya, tabel 4.12 menginformasikan kategori kontribusi setiap komponen pendapatan asli daerah (PAD) terhadap PAD kabupaten/kota di Provinsi Sulawesi Tengah 
tahun 2014-2018. Dari tabel tersebut terlihat bahwa kontribusi pajak daerah terhadap PAD kabupaten/kota sangat bervariasi. Disitu terlihat bahwa dari 13 kabupaten/kota, terdapat dua kabupaten/kota yang tingkat kontribusinya termasuk dalam kualifikasi sedang, yaitu Kabupaten Donggala dan Kota Palu, enam kabupaten/kota termasuk dalam kualifikasi cukup baik, yaitu Kabupaten Sigi, Kabupaten Banggai, Kabupaten Banggai Kepulauan, Kabupaten Morowali, Kabupaten Morowali Utara, dan Kabupaten Tojo Una-Una, sedangkan lima kabupaten/kota lainnya termasuk dalam kualifikasi kurang baik, yaitu Kabupaten Parigi Moutong, Kabupaten Poso, Kabupaten Tolitoli, Kabupaten Banggai Laut, dan Kabupaten Boul.

Tabel 4.12 tersebut pula menunjukkan bahwa kategori tingkat kontribusi retribusi daerah terhadap PAD kabupaten/kota di Provinsi Sulawesi Tengah sebagian besar tergolong dalam kualifikasi sangat kurang baik. Di dalam tabel tersebut dapat dilihat bahwa hanya dua kabupaten/kota yang memiliki tingkat kontribusi retribusi daerah terhadap PAD termasuk dalam kualifikasi baik, yaitu Kabupaten Banggai Laut dan Kabupaten Morowali. Kemudian, hanya Kabupaten Marowali Utara saja yang termasuk dalam kualifikasi sedang, begitupula Kabupaten Banggai tergolong dalam kualifikasi cukup baik. Sementara Kabupaten Poso, Kabupaten Tolitoli, dan Kabupaten Banggai Kepulauan termasuk dalam kualifikasi kurang baik. Sedangkan lebihnya, enam kabupaten/kota termasuk dalam kualifikasi sangat kurang baik, yaitu Kabupaten Parigi Moutong, Kabupaten Donggala, Kabupaten Sigi, Kabupaten Tojo una-una, Kabupaten Boul, dan Kota Palu.

Dari tabel 4.12 tersebut juga tergambar kategori tingkat kontribusi pengelolaan kekayaan daerah yang dipisahkan terhadap PAD kabupaten/kota di Provinsi Sulawesi Tengah tahun 2014-2019. Dari tabel tersebut dapat dijelaskan bahwa sebagian besar kontribusi pengelolaan kekayaan daerah yang dipisahkan termasuk dalam kualifikasi sangat kurang baik. Hal ini terlihat dari 13 kabupaten/kota di Provinsi Sulawesi Tengah, tujuh diantaranya termasuk dalam kualifikasi sangat kurang baik, yaitu Kabupaten Donggala, Kabupaten Sigi, Kabupaten Banggai, Kabupaten Banggai Laut, Kabupaten Morowali, Kabupaten Morowali Utara, dan Kota Palu. Di dalam tabel itu pula terlihat bahwa hanya Kabupaten Parigi Moutong yang termasuk dalam kualifikasi kurang baik, sementara empat kabupaten/kota sisanya termasuk dalam kualifikasi cukup baik, yaitu Kabupaten Poso, Kabupaten Tolitoli, Kabupaten Banggai Kepulauan, Kabupaten Tojo Una-una, Kabupaten Boul.

Pada tabel 4.12 di atas juga tertera kategori tingkat kontribusi lain-lain pendapatan asli daerah yang sah terhadap PAD kabupaten/kota di Provinsi Sulawesi Tengah tahun 2014-2018. Di sini tergambar bahwa mayoritas kontribusi lain-lain pendapatan asli daerah yang sah termasuk dalam kualifikasi sangat baik. Dari 13 kabupaten/kota di Provinsi Sulawesi Tengah, terdapat delapan kabupaten/kota yang termasuk dalam kualifikasi sangat baik, yaitu Kabupaten Parigi Moutong, Kabupaten Donggala, Kabupaten Sigi, Kabupaten Tolitoli, Kabupaten Banggai 
Kepulauan, Kabupaten Tojo Una-una, Kabupaten Boul, dan Kota Palu. Kemudian, hanya Kabupaten Poso yang termasuk dalam kualifikasi baik. Sementara empat kabupaten/kota sisanya termasuk dalam kualifikasi sedang, yaitu Kabupaten Banggai, Kabupaten Banggai Laut, Kabupaten Morowali, dan Kabupaten Morowali Utara.

Kemudian, secara keseluruhan terkait dengan kategori tingkat pertumbuhan pendapatan asli daerah (PAD) dijelaskan pada tabel 15 di bawah ini. Merujuk pada tabel tersebut, ditujukkan bahwa dari 13 kabupaten/kota di Provinsi Sulawesi Tengah, terdapat tiga kabupaten/kota, yaitu Kabupaten Poso, Kabupaten Banggai, dan Kabupaten Morowali yang sangat berhasil meningkatkan pertumbuhan pendapatan asli daerahnya. Kemudian, terdapat satu kabupaten/kota yang termasuk dalam kualifikasi berhasil, yaitu Kabupaten Banggai Laut. Sementara Kabupaten Sigi, Kabupaten Tolitoli, Kabupaten Tojo Una-Una termasuk dalam kualifikasi kurang berhasil, sedangkan enam kabupaten/kota lainnya termasuk dalam kualifikasi tidak berhasil, yaitu Kabupaten Parigi Moutong, Kabupaten Donggala, Kabupaten Banggai Kepulauan, Kabupaten Morowali Utara, Kabupaten Buol, dan Kota Palu.

Disisi lain pada tabel 15 di atas, juga menunjukkan kategori tingkat kontribusi PAD terhadap pendapatan daerah kabupaten/kota di Provinsi Sulawesi Tengah selama lima tahun (2014-2018). Dari tabel tersebut terlihat bahwa hanya Kabupaten Poso yang tingkat kontribusi PAD terhadap pendapatan daerah termasuk dalam kualifikasi cukup baik. Kemudian, hanya Kabupaten Morowali dan Kota Palu termasuk dalam kualifikasi kurang baik. Sedangkan sebagian besar lainnya termasuk dalam kualifikasi sangat kurang baik, yaitu Kabupaten Parigi Moutong, Kabupaten Donggala, Kabupaten Sigi, Kabupaten Tolitoli, Kabupaten Banggai, Kabupaten Banggai Laut, Kabupaten Banggai Kepulauan, Kabupaten Morowali Utara, Kabupaten Tojo Una-una, Kabupaten Boul.

\section{Kesimpulan, Keterbatasan, dan Saran}

\subsection{Kesimpulan}

Secara umum penelitian ini bertujuan untuk mengetahui tingkat pertumbuhan dan kontribusi komponen pendapatan asli daerah (PAD) terhadap PAD. Selain itu, penelitian ini juga bertujuan untuk mengetahui tingkat pertumbuhan PAD dan kontribusinya terhadap pendapatan daerah. Jenis penelitian ini adalah penelitian kualitatif deskriptif. Penelitian ini dilakukan pada Kabupaten/Kota di Provinsi Sulawesi Tengah. Data yang digunakan dalam penelitian ini adalah data sekunder berupa realisasi PAD berserta komponennya, dan realisasi pendapatan daerah tahun 2014-2018. Berdasarkan hasil analisis deskriptif ditemukan bahwa rata-rata tingkat pertumbuhan komponen PAD di atas dari 50 persen hanya lain-lain pendapatan asli daerah 
yang sah dan termasuk dalam kategori sangat berhasil. Sementara komponen lainnya, yaitu pajak daerah, retribusi daerah, pengelolaan keuangan daerah yang dipisahkan masing-masing tingkat pertumbuhannya kurang dari 30 persen dan termasuk dalam kategori sangat tidak berhasil. Sedangkan dari sisi kontribusi terhadap PAD kabupaten/kota, ditemukan bahwa ratarata tingkat kontribusi pajak daerah sebesar 20 persen hingga 30 persen dan termasuk dalam kriteria cukup baik. Kemudian kontribusi retribusi daerah kabupaten/kota rata-rata kurang dari 10 persen dan termasuk dalam kualifikasi sangat kurang baik. Begitupula rata-rata kontribusi pengelolaan keuangan daerah yang dipisahkan dibawah 10 persen juga termasuk dalam kualifikasi sangat kurang baik. Selanjutnya, rata-rata tingkat kontribusi lain-lain pendapatan asli daerah yang sah adalah lebih besar dari 50 persen dan termasuk dalam kualifikasi sangat baik. Secara keseluruhan bahwa rata-rata pertumbuhan PAD sebesar 79.65 persen dan tingkat kontribusi PAD 9.02 persen. Dengan demikian, dapat dikatakan bahwa pertumbuhan PAD termasuk dalam kualifikasi berhasil dan tingkat kontribusinya terhadap pendapatan daerah termasuk dalam kualifikasi sangat kurang baik

\subsection{Keterbatasan}

Penelitian terbatas mengambarkan secara menyeluruh terkait dengan pertumbuhan dan kontribusi dari komponen PAD, maupun pertumbuhan dan kontribusi PAD terhadap pendapatan daerah. Sehingga, tidak dapat menunjukkan lebih detail pertumbuhan maupun kontribusi komposisi dari setiap jenis (komponen) PAD itu sendiri.

\subsection{Saran}

Penelitian selanjutnya dapat mengeksplorasi lebih jauh terkait dengan permasalahan yang dihadapi oleh pemerintah daerah dalam upaya meningkatkan pertumbuhan PAD dan kontribusi PAD terhadap pendapatan daerah. Sehingga, dapat ditemukan strategi maupun solusi dalam meningkatkan pertumbuhan PAD dan kontribusi PAD di masa mendatang.

\section{Daftar Pustaka}

Craw, M. 2010. Deciding to Provide: Local Decisions on Providing Social Welfare. American Journal of Political Science 54(4): 906-920.

Lindaman, K., K. Thurmaier, S.E. Development, C. Change, N. July, dan K. Lindaman. 2016. Beyond Efficiency and Economy: An Examination of Basic Needs and Fiscal Decentralization The University of Chicago Press Stable 50(4): 915-934.

Lobao, L., P.W. Jeanty, M. Partridge, dan D. Kraybill. 2012. Poverty and Place across the United States : Do County Governments Matter to the Distribution of Economic Disparities. 
International Regional Sage Review 35(2): 158-187.

Republik Indonesia. 2004. Undang-Undang No. 33 Tahun 2004 tentang Perimbangan Keuangan Antara Pusat dan Pemerintah Daerah. Sekretariat Negara. Jakarta. 2004. Undang-Undang No. 32 Tahun 2004 tentang Pemerintahan Daerah. Sekretariat Negara. Jakarta. 2009. Undang-Undang No. 28 Tahun 2009 tentang Pajak Daerah dan Retribusi Daerah. Sekretariat Negara. Jakarta. 2007. Peraturan Menteri Dalam Negeri No. 59 tahun 2007 tentang Perubahan Atas Peraturan Menteri Dalam Negeri No. 13 tahun 2006 tentang Pedoman Pengelolaan Keuangan Daerah. Sekretariat Negara. Jakarta.

2011. Peraturan Menteri Dalam Negeri No. 21 tahun 2011 tentang Perubahan Kedua Atas Peraturan Menteri Dalam Negeri No. 13 tahun 2006 tentang Pedoman Pengelolaan Keuangan Daerah. Sekretariat Negara. Jakarta.

Sartika, D., A. Ulfa, dan A. llyas. 2019. Analisis potensi penerimaan pajak daerah dan retribusi daerah terhadap Pendapatan Asli Daerah (PAD) Kabupaten/Kota di Provinsi Jawa Barat. Jurnal Ekonomi \& Bisnis Dharma Andalas 21(1): 32-53.

Sugiyono. 2014. Metode Penelitian Kuantitatif, Kuaitatif, Dan R\&D (Metode Penelitian Bisnis). Bandung: Alfabeta.

Syamsul, S., dan L. Fifiani. 2019. Review Pendapatan Asli Daerah: Pendekatan Analisis Horisontal dan Vertikal. Gorontalo Development Review 2(2): 82-96. 